\title{
Serum protein changes in breast cancer: a prospective study
}

\author{
K. W. PETtingale AND D. E. H. TEE \\ From Faith Courtauld Unit for Human Studies in Cancer, King's College Hospital Medical School, \\ London SE5 9RS, UK
}

SUMMARY Sixty women admitted to the King's College Hospital group for biopsy of a lump in the breast have been followed sequentially for one year. Thirty women had early operable breast cancer and 30 had benign breast disease. Each patient had 10 serum proteins measured preoperatively and postoperatively at three months and at one year. The patients with breast cancer had significantly higher levels of $\beta_{2}$ glycoprotein preoperatively and caeruloplasmin at one year postoperatively than those with benign breast disease. There were a number of significant correlations between serum protein levels and the progression of breast cancer as measured by the clinical score. There were significant correlations with caeruloplasmin preoperatively and at three months postoperatively. Prealbumin and haemopexin showed correlations preoperatively; $\alpha_{1}$ antitrypsin and $\beta_{2}$ glycoprotein only correlated at three months postoperatively. A longer follow-up will be required to establish the value of serum protein changes which could predict the development of metastases in patients with breast cancer.

Changes in the various fractions of serum proteins, particularly alpha glycoproteins, have been reported many times in cancer patients (Winzler and Smyth, 1948; Bacchus et al., 1967; Snyder and Ashwell, 1971), and although similar changes are seen in many non-malignant conditions, eg, inflammation, the measurement of specific glycoproteins has indicated that specific protein profiles may exist for malignant and non-malignant disease, and even for different types of malignancy (Snyder and Ashwell, 1971; McPhedran et al., 1972; Douma and Van Dalen, 1974).

Unfortunately, in spite of a considerable number of serum protein surveys performed in cancer patients, many of the reports are not comparable or conflict with each other. Many studies have not been confined to a single type of cancer nor taken account of the extent of the disease; the nature, age, and state of health of the control subjects has usually not been considered, and no study has reported serum protein changes followed serially in the same subjects over an extended period of time.

This study was undertaken to determine (a) whether a diagnostic profile of plasma protein changes occurs in early breast cancer compared to non-malignant breast disease; and $(b)$ whether plasma

Received for publication 11 May 1977 protein changes in breast cancer patients followed prospectively could be correlated with the spread of the tumour. The results of the first year are reported here.

\section{Patients and methods}

Sixty women admitted to King's College Hospital for biopsy of a lump in the breast have been studied. Thirty of these women were found to have breast cancer and 30 to have non-malignant breast disease. All the women were aged less than 70 years and had breast lumps less than $5 \mathrm{~cm}$ in diameter, with or without palpable ipsilateral axillary glands. Those with breast cancer therefore had tumours which fell into clinical stage I or II of the Manchester classification (Wise et al., 1971) and had no evidence of clinically occult metastases as shown by routine chest $x$-ray, full blood count, and serum chemistry (serum bilirubin, alkaline phosphatase, aspartate transaminase and hydroxybutyrate dehydrogenase, calcium, phosphate, uric acid, sodium, potassium and urea) or bone scanning.

The two groups of women had venous blood sampled the day before operation and at three months and one year postoperatively.

A careful clinical record has been kept of each cancer patient and of the patients with benign 
breast disease. A system of quantifying the approximate tumour mass in each cancer patient was devised to produce the clinical score, so that correlations between the protein changes and extent of the cancer could be performed. This scoring system was based upon the diameter of the breast tumour measured postoperatively, and additional points were given for evidence of histological spread of the tumour to involve skin, pectoral muscles or lymph nodes. Postoperatively the score was increased for local recurrence of the tumour in the scar or lymph nodes and for the development of each metastatic lesion confirmed by biopsy. Equal weighting was given to proven metastases irrespective of site, and the score was modified if a lesion increased or decreased in size. A reduced weighting was given to symptoms or investigations which suggested metastatic spread before a lesion was confirmed, eg, persistent backache' .

Serum was separated from the blood samples, divided into aliquots, coded, and stored at $-20^{\circ} \mathrm{C}$. Samples were randomised and analysed in batches of 50 .

Estimations of 10 serum proteins were made using single radial immunodiffusion on commercial Tripartigen plates (Hoechst Ltd). These were albumin, pre-albumin, $\alpha_{1}$ acid glycoprotein, $\alpha_{1}$ antitrypsin, $\alpha_{2}$ HS glycoprotein, $\beta_{2}$ glycoprotein, caeruloplasmin, haptoglobin, haemopexin, and transferrin.

\section{STATISTICAL METHODS}

The serum protein levels for each patient were coded onto punched cards and analysed by computer. The distributions of most of the serum proteins were found to be log-normal, and statistical comparisons with such proteins were made on logarithmic data.

\section{Results}

COMPARISON BETWEEN THE TWO DIAGNOSTIC POPULATIONS

Preoperatively $\beta_{2}$ glycoprotein was significantly higher in the cancer patients $(P<0.015)$ but none of the other protein levels was significantly different in the two diagnostic groups (Table 1).

At three-month follow-up there were no significant differences between the mean levels of any of the proteins in the two diagnostic groups (Table 1).

At one year follow-up the mean level of caeruloplasmin was significantly higher in the cancer patients than in the benign group $(P<0.031)$ (Table 1).

${ }^{1}$ Further details of the scoring system may be obtained from the authors.
CORRELATIONS OF SERUM PROTEIN LEVELS WITH PATIENT'S AGE

Although the mean ages of the two diagnostic groups differed significantly (benign 44 years; cancer 52 years), correlation analysis between serum protein levels and the ages of the patients in both groups failed to reveal any statistically significant relationship at any time.

CORRELATION OF INDIVIDUAL SERUM PROTEINS WITH TIME

Correlation analysis between the serum protein levels at the different time points revealed generally good correlations between levels of single proteins at the different times, particularly among the benign group (Table 2 ). Haptoglobin, $\beta_{2}$ glycoprotein, and caeruloplasmin levels showed the most internal consistency in both groups of patients.

$\alpha_{1}$ Antitrypsin and transferrin levels were marginally more consistent in the cancer group than in the benign, but prealbumin, $\alpha_{1}$ acid glycoprotein, $\alpha_{2}$ HS glycoprotein, and haemopexin levels were less internally consistent in the cancer group.

CORRELATION BETWEEN DIFFERENT SERUM PROTEINS AT DIFFERENT TIMES

There were many correlations between different proteins at the various times but few were consistent with time or seen in both groups. The detailed correlation matrices are too extensive for inclusion in this paper.

The proteins that differed when the two populations were compared, ie, $\beta_{2}$ glycoprotein and caeruloplasmin, did not show any interrelationship.

CORRELATION OF SERUM PROTEIN LEVELS WITH CLINICAL SCORE

Correlations between the various serum proteins and the clinical scores of the cancer patients at the same time points are shown in Table 3 . There were significant correlations with caeruloplasmin preoperatively and at three months postoperatively. Pre-albumin and haemopexin showed correlations only preoperatively, and $\alpha_{1}$ antitrypsin and $\beta_{2}$ glycoprotein correlated only at three months postoperatively.

The distribution of clinical scores of the cancer patients at the three-month and one-year postoperative follow-up times is narrow and skewed as few patients have developed high scores by one year (Figure). This distribution probably accounts for the alteration in the direction of some of the correlations which is seen at different times. 
Table 1 Comparison of serum protein levels between patients with breast cancer and those with benign breast tumours

\begin{tabular}{|c|c|c|c|c|c|}
\hline \multirow[t]{2}{*}{ Proteins } & \multicolumn{2}{|l|}{ Cancer } & \multicolumn{2}{|l|}{ Benign tumour } & \multirow[b]{2}{*}{$\mathbf{p}$} \\
\hline & Mean & $S D$ & Mean & $S D$ & \\
\hline \multicolumn{6}{|c|}{ Serum albumin ${ }^{*}$} \\
\hline Preop. & $3302 \cdot 50$ & $1407 \cdot 23$ & 3615.00 & $1419 \cdot 39$ & NS \\
\hline $3 \mathrm{mth}$ & 3359.64 & 1000.05 & $3406 \cdot 88$ & 825.60 & NS \\
\hline $1 \mathrm{yr}$ & $4981 \cdot 43$ & $1661 \cdot 28$ & 5133.91 & $1501 \cdot 21$ & NS \\
\hline \multicolumn{6}{|c|}{ Pre-albumin $\dagger$} \\
\hline Preop. & $1.45(28.50)$ & 0.21 & $1.45(28 \cdot 18)$ & $0 \cdot 17$ & NS \\
\hline $3 \mathrm{mth}$ & $1.44(27.38)$ & $0 \cdot 16$ & $1.47(29.51)$ & 0.13 & NS \\
\hline $1 \mathrm{yr}$ & $1 \cdot 39(24.78)$ & $0 \cdot 14$ & $1.38(23.99)$ & $0 \cdot 15$ & NS \\
\hline \multicolumn{6}{|c|}{$a_{1}$ Acid glycoprotein $\dagger$} \\
\hline Preop. & $1 \cdot 78(60 \cdot 3)$ & $0 \cdot 15$ & $1 \cdot 79(61 \cdot 7)$ & $0 \cdot 21$ & NS \\
\hline $3 \mathrm{mth}$ & $1.77(58.9)$ & $0 \cdot 18$ & $1.72(52.5)$ & 0.26 & NS \\
\hline $1 \mathrm{yr}$ & $1.91(81 \cdot 3)$ & 0.20 & $1.81(64 \cdot 6)$ & $0 \cdot 19$ & NS \\
\hline \multicolumn{6}{|c|}{$a_{1}$ Antitrypsin $\dagger$} \\
\hline Preop. & $2 \cdot 17(147 \cdot 9)$ & 0.25 & $2 \cdot 28(190 \cdot 6)$ & $0 \cdot 19$ & NS \\
\hline $3 \mathrm{mth}$ & $2 \cdot 18(151 \cdot 4)$ & 0.23 & $2 \cdot 19(154.9)$ & 0.14 & NS \\
\hline $1 \mathrm{yr}$ & $2 \cdot 28(190 \cdot 6)$ & $0 \cdot 17$ & $2 \cdot 22(166 \cdot 0)$ & $0 \cdot 18$ & NS \\
\hline \multicolumn{6}{|c|}{$a_{3}$ HS Glycoprotein* } \\
\hline Preop. & $68 \cdot 54$ & 21.75 & 72.06 & $19 \cdot 17$ & NS \\
\hline $3 \mathrm{mth}$ & $66 \cdot 18$ & $21 \cdot 10$ & $70 \cdot 25$ & $19 \cdot 42$ & NS \\
\hline $1 \mathrm{yr}$ & $67 \cdot 18$ & 20.92 & $65 \cdot 38$ & 25.41 & NS \\
\hline \multicolumn{6}{|c|}{$\beta_{3}$ Glycoprotein $t$} \\
\hline Preop. & $1 \cdot 30(19 \cdot 95)$ & 0.09 & $1 \cdot 23(16.98)$ & $0 \cdot 11$ & $<0.015$ \\
\hline $3 \mathrm{mth}$ & $1.36(22.91)$ & $0 \cdot 14$ & $1.36(22.91)$ & $0 \cdot 16$ & NS \\
\hline $1 \mathrm{yr}$ & $1 \cdot 20(15 \cdot 85)$ & $0 \cdot 17$ & $1 \cdot 14(13 \cdot 80)$ & $0 \cdot 14$ & NS \\
\hline \multicolumn{6}{|c|}{ Caeruloplasmint } \\
\hline Preop. & $1 \cdot 45(28 \cdot 18)$ & 0.20 & $1.38(23.99)$ & $0 \cdot 20$ & NS \\
\hline $3 \mathrm{mth}$ & $1.55(35.48)$ & 0.11 & $1.54(34.67)$ & $0 \cdot 10$ & NS \\
\hline $1 \mathrm{yr}$ & $1.52(33.11)$ & 0.15 & $1.42(26 \cdot 30)$ & $0 \cdot 19$ & $<0.031$ \\
\hline \multicolumn{6}{|c|}{ Haemopexin $\dagger$} \\
\hline Preop. & $1 \cdot 78(60 \cdot 26)$ & 0.13 & $1 \cdot 75(56 \cdot 24)$ & $0 \cdot 11$ & NS \\
\hline $3 \mathrm{mth}$ & $1.85(70.79)$ & $0 \cdot 10$ & $1.86(72.44)$ & 0.07 & NS \\
\hline $1 \mathrm{yr}$ & $1.87(74 \cdot 14)$ & $0 \cdot 11$ & $1.83(67.61)$ & $0 \cdot 15$ & NS \\
\hline \multicolumn{6}{|c|}{ Haptoglobin $\dagger$} \\
\hline Preop. & $2 \cdot 34(218 \cdot 77)$ & 0.24 & $2 \cdot 29(194.98)$ & $0 \cdot 26$ & NS \\
\hline $3 \mathrm{mth}$ & $2 \cdot 27(186.20)$ & $0 \cdot 20$ & $2 \cdot 18(151 \cdot 36)$ & 0.21 & NS \\
\hline $1 \mathrm{yr}$ & $2 \cdot 38(239 \cdot 86)$ & $0 \cdot 20$ & $2.32(208.92)$ & 0.21 & NS \\
\hline \multicolumn{6}{|c|}{ Transferrin $†$} \\
\hline Preop. & $2 \cdot 36(229.08)$ & $0 \cdot 16$ & $2.33(213.78)$ & $0 \cdot 18$ & NS \\
\hline $3 \mathrm{mth}$ & $2.53(338.82)$ & 0.17 & $2.47(295 \cdot 12)$ & $0 \cdot 18$ & NS \\
\hline $1 \mathrm{yr}$ & $2.55(354.80)$ & 0.08 & $2.54(346.73)$ & 0.07 & NS \\
\hline
\end{tabular}

* Proteins with normal distributions have their mean values expressed as $\mathrm{mg} / 100 \mathrm{ml}$.

†Proteins with log-normal distributions have their mean values shown as logarithms to base 10 with the antilog of the mean expressed in $\mathrm{mg} / 100 \mathrm{ml}$ in parentheses.

NS = not significant.

\section{Discussion}

There appear to be differences in the serum protein levels between women with breast cancer and those with benign breast disease. These differences are seen preoperatively at the earliest time of clinical detection of a breast tumour and do not appear to be related to the age difference between the groups.

Raised serum caeruloplasmin has been reported previously in patients with both cancer and chronic inflammatory diseases (Sternlieb and Scheinberg, 1961; Snyder and Ashwell, 1971), but an increase in $\beta_{2}$ glycoprotein levels does not appear to have been reported before. In previous studies the levels have been either unchanged (Cleve, 1968) or reduced (Snyder and Ashwell, 1971). Our study, however, is confined to one type of cancer at an early stage and is not strictly comparable with the previous studies quoted.
Although comparison of the two groups of patients has revealed only differences in caeruloplasmin and $\beta_{2}$ glycoprotein levels, the correlation analyses suggest that the metabolism of serum glycoproteins may be altered more fundamentally.

Although caeruloplasmin and $\beta_{2}$ glycoprotein levels correlated with the clinical score at certain times, a number of other glycoproteins are also $\frac{7}{2}$ correlated with the spread of breast cancer. It would therefore be unwise to restrict further surveys in $\tilde{N}$ cancer patients only to those serum proteins which $N$ are different from those of patients with benign disease.

The clinical scoring system does attempt to quantify the tumour mass and thus enable cor- $\stackrel{\circ}{\mathbb{C}}$

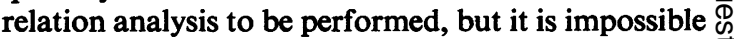
to detect subclinical spread of breast cancer, and the scoring system must clearly underestimate the tumour mass of many patients. At present few of 
Table 2 Correlations between individual protein levels at different times

\begin{tabular}{|c|c|c|c|c|}
\hline Group & Protein & $\begin{array}{l}\text { Preopera- } \\
\text { tive with } \\
3 \text { months } \\
\text { postopera- } \\
\text { tive }\end{array}$ & $\begin{array}{l}\text { Preopera- } \\
\text { tive with } \\
12 \text { months } \\
\text { postopera- } \\
\text { tive }\end{array}$ & $\begin{array}{l}3 \text { months } \\
\text { postopera- } \\
\text { tive with } \\
12 \text { months } \\
\text { postopera- } \\
\text { tive }\end{array}$ \\
\hline \multirow[t]{10}{*}{ Benign } & Albumin & 0.04 & $0 \cdot 10$ & 0.06 \\
\hline & Prealbumin & 0.29 & 0.49 & 0.42 \\
\hline & $a_{1}$ Acid glycoprotein & $0 \cdot 34$ & $0 \cdot 39$ & $0 \cdot 36$ \\
\hline & $a_{1}$ Antitrypsin & $0 \cdot 34$ & 0.31 & $0 \cdot 12$ \\
\hline & $a_{2}$ HS Glycoprotein & 0.04 & $0 \cdot 17$ & 0.44 \\
\hline & $\beta_{2}$ Glycoprotein & 0.64 & 0.51 & $0 \cdot 27$ \\
\hline & Caeruloplasmin & 0.56 & 0.62 & 0.21 \\
\hline & Haemopexin & 0.47 & 0.43 & $0 \cdot 10$ \\
\hline & Haptoglobin & 0.74 & 0.50 & 0.50 \\
\hline & Transferrin & 0.23 & $0 \cdot 10$ & 0.04 \\
\hline \multirow[t]{10}{*}{ Cancer } & Albumin & $0 \cdot 20$ & $0 \cdot 22$ & 0.13 \\
\hline & Prealbumin & $0 \cdot 10$ & $0 \cdot 11$ & 0.32 \\
\hline & $a_{1}$ Acid glycoprotein & $0 \cdot 12$ & 0.01 & 0.58 \\
\hline & $a_{1}$ Antitrypsin & 0.47 & 0.44 & $0 \cdot 30$ \\
\hline & $a_{2}$ HS Glycoprotein & 0.03 & $0 \cdot 23$ & 0.04 \\
\hline & $\beta_{2}$ Glycoprotein & 0.43 & 0.53 & 0.34 \\
\hline & Caeruloplasmin & 0.40 & 0.62 & $0 \cdot 14$ \\
\hline & Haemopexin & 0.02 & 0.09 & $0 \cdot 18$ \\
\hline & Haptoglobin & 0.56 & 0.35 & 0.35 \\
\hline & Transferrin & $0 \cdot 30$ & $0 \cdot 16$ & 0.29 \\
\hline
\end{tabular}

Values shown are Pearson correlation coefficient $r$.

Table 3 Correlation between serum proteins and clinical scores in patients with breast cancer

\begin{tabular}{lccc}
\hline Protein & $\begin{array}{l}\text { Preoperative } \\
\text { correlation }\end{array}$ & $\begin{array}{c}\text { Postoperative } \\
-3 \text { month } \\
\text { correlation }\end{array}$ & $\begin{array}{c}\text { Postoperative } \\
-1 \text { year } \\
\text { correlation }\end{array}$ \\
\hline Albumin & 0.15 & -0.13 & 0.21 \\
Prealbumin & $-0.36^{*}$ & -0.05 & -0.16 \\
$a_{1}$ Acid glycoprotein & -0.04 & -0.32 & 0.12 \\
$a_{1}$ Antitrypsin & 0.16 & $0.41^{*}$ & 0.22 \\
$a_{2}$ HS Glycoprotein & -0.13 & 0.28 & -0.08 \\
$\beta_{2}$ Glycoprotein & -0.23 & $0.36^{*}$ & -0.16 \\
Caeruloplasmin & $-0.36^{*}$ & $0.36^{*}$ & 0.14 \\
Haemopexin & $-0.36^{*}$ & 0.05 & 0.17 \\
Haptoglobin & -0.02 & 0.01 & -0.29 \\
Transferrin & -0.04 & -0.03 & -0.02 \\
\hline
\end{tabular}

*Statistically significant

$P<0.05$

Values shown are Pearson correlation coefficient $r$.

our patients have developed metastatic disease and hence high scores and it is too early to detect any clear or simple pattern of glycoprotein changes emerging which correlates with progression of breast cancer.

The biological functions of many of these glycoproteins are numerous and not all are known, neither is the mechanism by which changes are induced by cancer. It is possible that glycoproteins are synthesised directly by the tumour, but in view of the diversity of protein changes, it seems more likely that the malignant process is indirectly affecting the metabolism of these proteins. Their synthesis in the liver is known to be influenced by many hormones (Hoch-Ligeti and Irvine, 1954; Good et al., 1971) and we are currently investigating

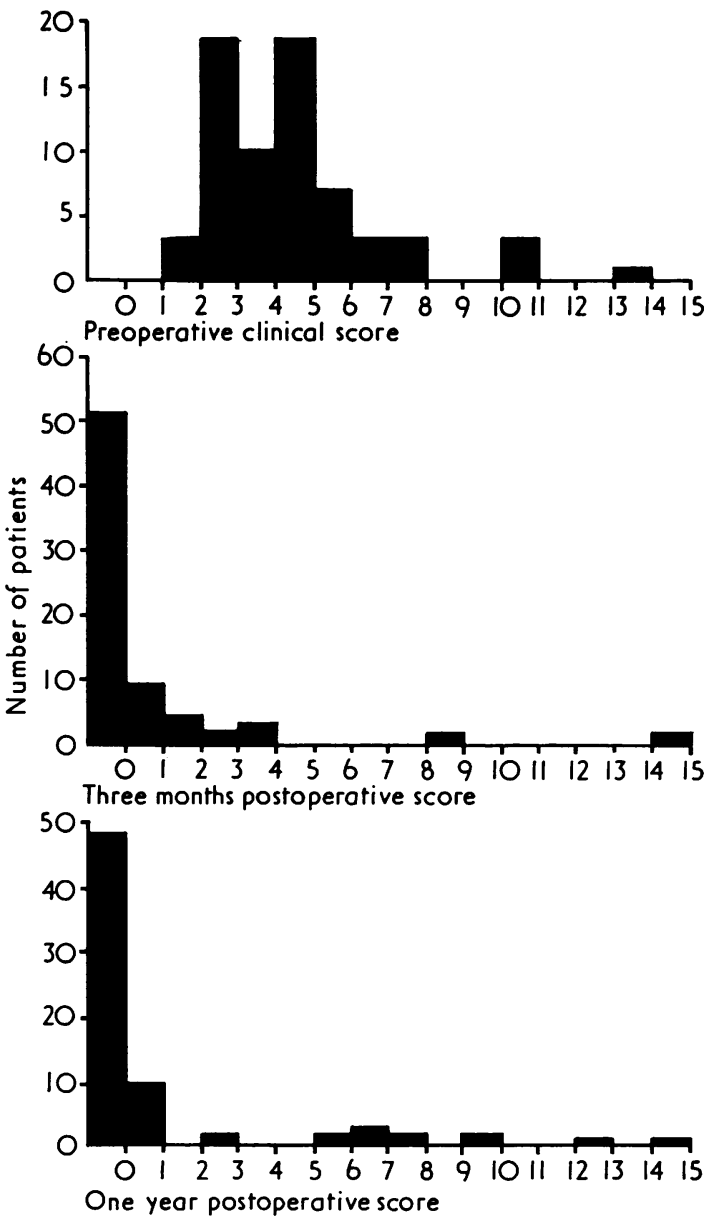

Figure Skewed distribution of clinical scores at different times, from a larger series of breast cancer patients, including those patients currently reported.

the relationship of hormone and protein changes in our cancer patients.

In view of the comparatively long natural history of breast cancer, the prospective follow-up of cancer patients needs to be several years longer to establish the value of any prognostic profile of serum protein changes. We are therefore continuing this comprehensive survey in order to investigate the relationship of serum protein changes to the pathogenesis of breast cancer.

We thank Patricia White and Kevin Ryan for help with the statistical analysis; we are grateful to the patients for their willing co-operation and to our colleagues on the Faith Courtauld Unit for Human Studies in Cancer at King's College Hospital Medical School for their help. 


\section{References}

Bacchus, H., Kennedy, E. R., and Blackwell, J.(1967). Qualitative and quantitative alterations in serum seromucoid in malignant neoplastic disease. Cancer (Philad.), 20, 1654-1662.

Cleve, H. (1968). Genetic studies on the deficiency of beta-2-glycoprotein I of human serum. Humangenetik 5, 294-304.

Douma, G. J., and van Dalen, A. (1974). An evaluation of the diagnostic value of haptoglobin and transferrin levels in serum. Zeitschrift für klinische Chemie und klinische Biochemie, 12, 474-476.

Good, W., Hancock, K. W., and Macdonald, H. N. (1971). The seromucoid glycoprotein subfraction in pregnancy and the early puerperium. Journal of Obstetrics and Gynaecology of the British Commonwealth, 78, 628-631.

Hoch-Ligeti, C., and Irvine, K. (1954). Effects of hormone administration on serum protein patterns. Proceedings of the Society for Experimental Biology and Medicine, 87, 324-332.

McPhedran, P., Finch, S. C., Nemerson, Y. R., and Barnes, M. G. (1972). Alpha-2 globulin "spike" in renal carcinoma. Annals of Internal Medicine, 76, 439-441.

Snyder, S., and Ashwell, G. (1971). Quantitation of specific serum glycoproteins in malignancy. Clinica Chimica Acta, 34, 449-455.

Sternlieb, I., and Scheinberg, I. H. (1961). Ceruloplasmin in health and disease. Annals of the New York Academy of Sciences, 94, 71-76.

Winzler, R. J., and Smyth, I. M. (1948). Studies on the mucoproteins of human plasma. II: Plasma mucoprotein levels in cancer patients. Journal of Clinical Investigation, 27, 617-619.

Wise, L., Mason, A. Y., and Ackerman, L. V. (1971). Local excision and irradiation: an alternative method for the treatment of early mammary cancer. Annals of Surgery, 174, 392-401. 